\title{
Mutations in the paralogous human $\alpha$-globin genes yielding identical hemoglobin variants
}

\author{
Kamran Moradkhani • Claude Préhu • John Old • \\ Shirley Henderson • Vera Balamitsa • Hong-Yuan Luo • \\ Man-Chiu Poon • David H. K. Chui • Henri Wajeman • \\ George P. Patrinos
}

Received: 16 October 2007 / Accepted: 25 September 2008 /Published online: 16 October 2008

(C) The Author(s) 2008. This article is published with open access at Springerlink.com

\begin{abstract}
The human $\alpha$-globin genes are paralogues, sharing a high degree of DNA sequence similarity and producing an identical $\alpha$-globin chain. Over half of the $\alpha$ globin structural variants reported to date are only characterized at the amino acid level. It is likely that a fraction of these variants, with phenotypes differing from one observation to another, may be due to the same mutation but on a different $\alpha$-globin gene. There have been very few previous examples of hemoglobin variants that can be found at both $H B A 1$ and $H B A 2$ genes. Here, we report the results of a systematic multicenter study in a large multiethnic population to identify such variants and to analyze their differences from a functional and evolutionary perspective. We identified 14 different $\mathrm{Hb}$ variants resulting from identical mutations on either one of the two human $\alpha$-globin paralogue genes. We also showed that the average percentage of hemoglobin variants due to a $H B A 2$ gene mutation $(\alpha 2)$ is higher than the percentage of hemoglobin
\end{abstract}

Electronic supplementary material The online version of this article (doi:10.1007/s00277-008-0624-3) contains supplementary material, which is available to authorized users.

\author{
K. Moradkhani $\cdot$ C. Préhu $\cdot$ H. Wajcman \\ Biochimie Génétique, AP-HP, Hôpital Henri Mondor, \\ 94010 Créteil, France \\ K. Moradkhani $\cdot$ C. Préhu $\cdot$ H. Wajcman \\ INSERM, U841, \\ 94010 Créteil, France \\ J. Old $\cdot$ S. Henderson \\ National Haemoglobinopathy Reference Laboratory, \\ Oxford Haemophilia Centre, Churchill Hospital, \\ Oxford, UK \\ V. Balamitsa \\ Unit for Prevention of Thalassemia, Trikala General Hospital, \\ Trikala, Greece
}

variants due to the same $H B A 1$ gene mutation $(\alpha 1)$ and that the $\alpha 2 / \alpha 1$ ratio varied between variants. These $\alpha$-globin chain variants have most likely occurred via recurrent mutations, gene conversion events, or both. Based on these data, we propose a nomenclature for hemoglobin variants that fall into this category.

Keywords $\alpha$-Globin genes · Paralogues · Gene conversion . Hemoglobin variants $\cdot$ Mutations

\section{Introduction}

There are close to 1,000 human hemoglobin $(\mathrm{Hb})$ variants reported to date $[1,2]$, and new ones are still being discovered. The vast majority of them are rare, while others, e.g., $\mathrm{Hb} \mathrm{S}, \mathrm{Hb} \mathrm{C}$, and $\mathrm{Hb} \mathrm{E}$, reach high frequencies in specific population groups [3]. Most $\mathrm{Hb}$ variants are

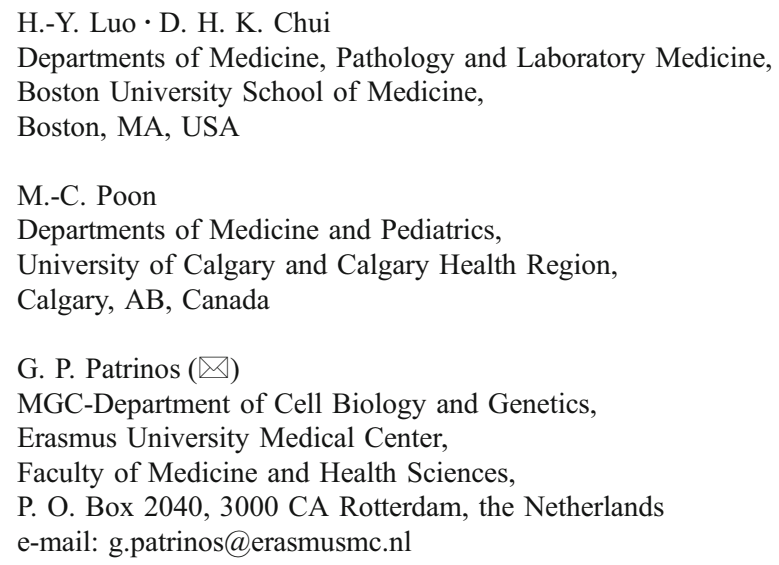


clinically and hematologically silent, but some cause hemolytic anemia, e.g., $\mathrm{Hb} \mathrm{S}$, some are unstable $\mathrm{Hbs}$, methemoglobinemia (Hbs M), and some cause cyanosis (Hb Kansas) or polycythemia due to their increased oxygen affinity ( $\mathrm{Hb}$ Ypsilanti, $\mathrm{Hb}$ Malmö). There are still other $\mathrm{Hb}$ variants that also lead to thalassemic phenotype ( $\mathrm{Hb} \mathrm{E}, \mathrm{Hb}$ Knossos).

The human $\alpha$-like globin gene cluster resides on the telomeric region of chromosome 16. The $H B A 2$ and $H B A 1$ genes are paralogues, i.e., set of homologous genes that have evolved from gene duplication and can be associated with a subsequent divergence of function. Both genes have an almost identical DNA sequence due to sequence homogenization by a gene conversion event [4]. Each gene yields an identical 141-amino acid-long $\alpha$-globin chain, which participates with a $\beta$-like globin chain to form the $\mathrm{Hb}$ tetramers. From the $332 \alpha$-globin chain variants identified to date, approximately $52 \%$ have been only characterized by protein chemistry methods, which creates uncertainty as to which $\alpha$ globin gene is mutated (Table 1). It is likely that a fraction of these variants may result from the same mutation but on a different $\alpha$-globin gene. Identification and comparative study of these variants would not only provide useful insights into $\alpha$-globin gene transcription and translation but can also shed light into the mechanistic properties of sequence diversification of the $\alpha$-like globin genes. There have been very few examples of $\mathrm{Hb}$ variants that have been previously identified at both $H B A 1$ and $H B A 2$ genes, namely Hb Frankfurt [5] and $\mathrm{Hb} \mathrm{I}$ [6]. Moreover, as the vast majority of $\mathrm{Hb}$ variants are rare, identification and comparative analysis of heterozygous cases for these variants is problematic, even for laboratories with large sample volumes.

Here, we report our results from a multicenter study to identify and comparatively analyze $\mathrm{Hb}$ variants that result from the same mutation but on different $\alpha$-globin gene paralogues in a large multiethnic population sample. In addition, we performed a systematic study in the HbVar database of $\mathrm{Hb}$ variants and thalassemia mutations (http:// globin.bx.psu.edu/hbvar; [1, 3]) to reveal other globin chain variants that fall into this category. Based on these results, we propose a nomenclature for related $\mathrm{Hb}$ variants.

Table 1 Number of hemoglobin variants due to a mutant human $\alpha$ globin gene

\begin{tabular}{lc}
\hline Globin genes & No. of $\mathrm{Hb}$ variants \\
\hline$H B A 2$ & 95 \\
$H B A 1$ & 54 \\
$H B A 2$ or $H B A 1$ unknown & 173 \\
Found in both $H B A 2$ or $H B A 1$ & 14 \\
Total & 332
\end{tabular}

${ }^{a}$ Data from HbVar database (http://globin.bx.psu.edu/hbvar, assessed in August 2007)

\section{Materials and methods}

Case selection

One hundred and one unrelated individuals, referred to the Unit of Biochemical Genetics, Henri Mondor Hospital (Créteil, France), National Haemoglobinopathy Reference Laboratory, Churchill Hospital, (Oxford, UK), Unit of Prevention of Thalassemia, Trikala General Hospital (Trikala, Greece), and Department of Pathology and Laboratory Medicine, Boston University (Boston, USA), were selected for this study. These subjects were previously identified as carriers of an $\mathrm{Hb}$ variant. Hematological indices were measured using a Coulter Cell Counter.

Additionally, 64 unrelated cases were identified in HbVar database of hemoglobin variants and thalassemia mutations (http://globin.bx.psu.edu/hbvar) and comparatively analyzed [7, 8]. Finally, additional data were extracted from Online Mendelian Inheritance in Man, where available (see Tables 2 and 3 for details).

\section{Identification of $\mathrm{Hb}$ variants}

Each sample was analyzed by cation-exchange high-performance liquid chromatography (HPLC) using the Hb Variant I or II systems with either the 6-min $\beta$-Thalassemia short or the Dual Kit program (BioRad Laboratories, Hercules, CA, USA). In addition, samples from the National Haemoglobinopathy Reference Laboratory were analyzed by isoelectric focusing, those from Trikala General Hospital were analyzed by alkaline agarose gel electrophoresis (Hydragel Hemoglobin 7, SEBIA Norcross, GA, USA) and isoelectric focusing, and samples from Henri Mondor Hospital were characterized using a battery of electrophoretic and chromatographic tests (IEF, citrate agar gel electrophoresis, globin chain electrophoresis at acid and alkaline $\mathrm{pH}$ and in the presence of Triton $\mathrm{X}$ 100, CE-HPLC, RP-HPLC), matching perfectly with results obtained with $\mathrm{Hb}$ samples structurally identified as previously described [9].

DNA was isolated from blood leukocytes, and amplification of the $H B A 2, H B A 1$, and $H B B$ genes was done using gene-specific primers [10]. DNA sequence analysis was performed with an automated sequencer (ABI 310, Applied Biosystems, Foster City, CA, USA, or CEQ 8000, Beckman Coulter, Fullerton, CA, USA). Detection of $\alpha$-thalassemia deletional mutants was carried out by a gap-PCR procedure [11].

\section{Results}

Fourteen different $\mathrm{Hb}$ variants, resulting from identical mutations on either one of the two human $\alpha$-globin 


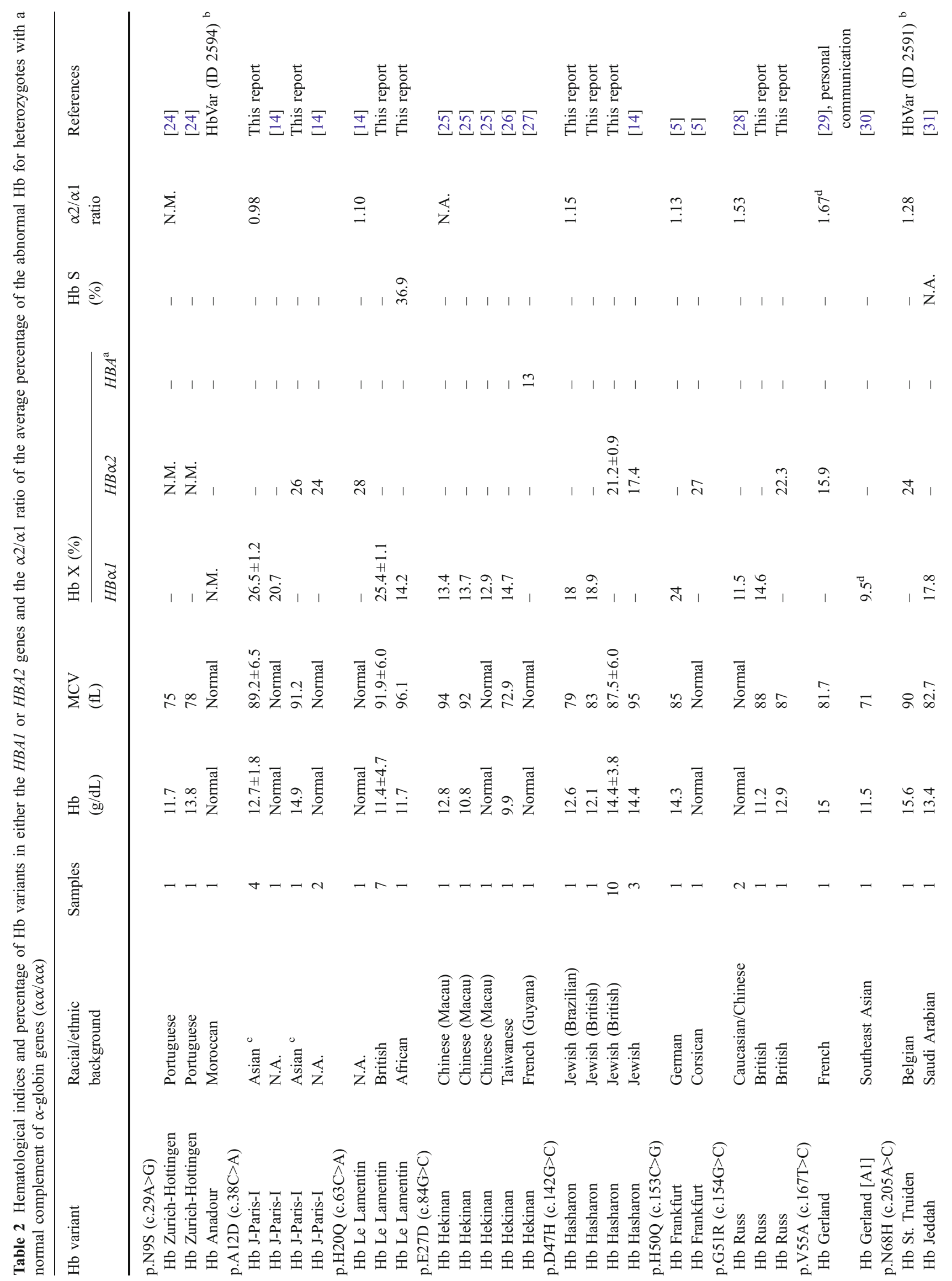




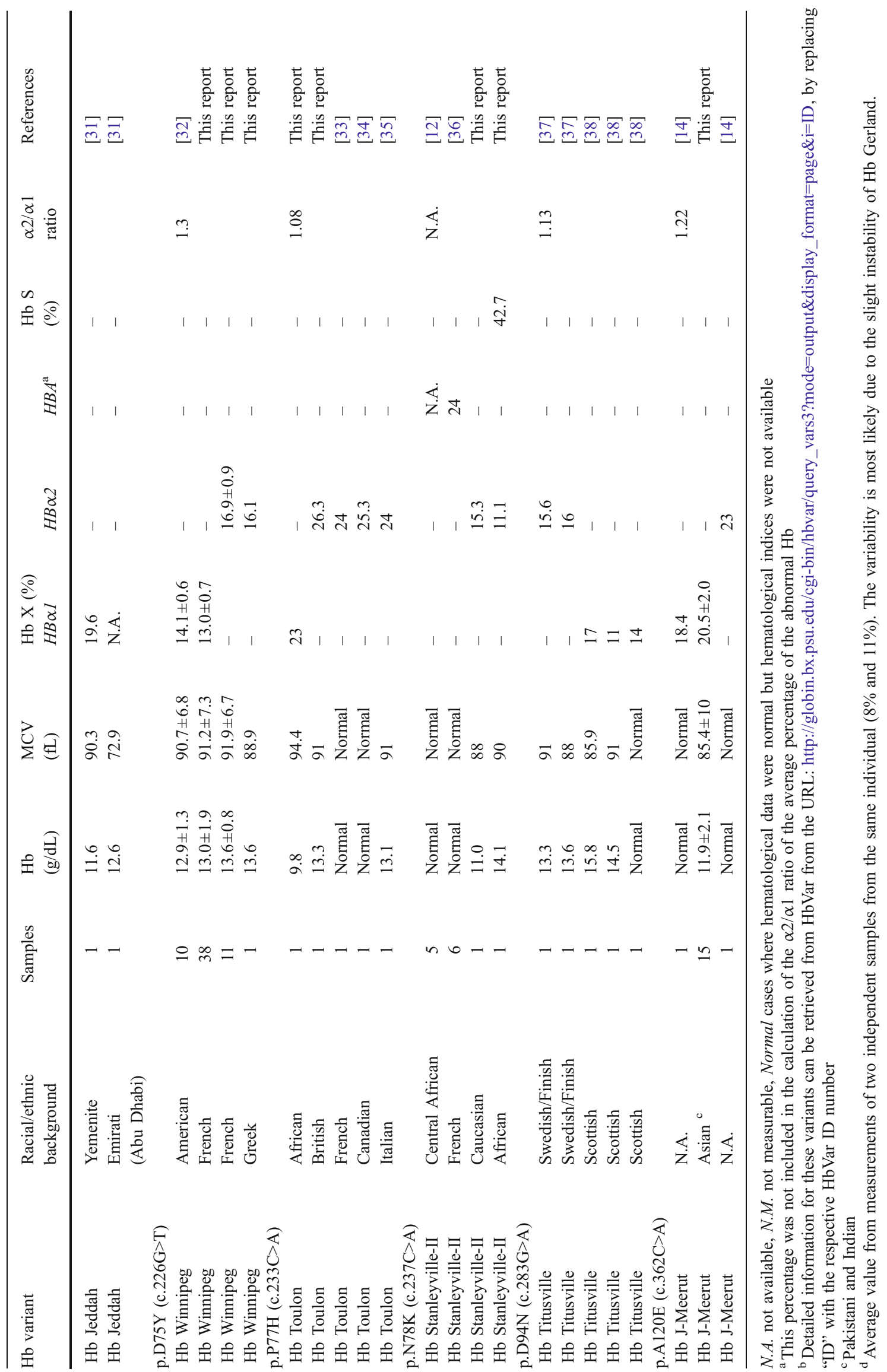


Table 3 Hematological indices and percentage of $\mathrm{Hb}$ variants in either the HBA1 or HBA2 genes for heterozygotes with an $\alpha$-thalassemia phenotype $(-\alpha / \alpha \alpha$ or $--/ \alpha \alpha)$

\begin{tabular}{|c|c|c|c|c|c|c|c|c|c|}
\hline \multirow[t]{2}{*}{$\mathrm{Hb}$ variant } & \multirow{2}{*}{$\begin{array}{l}\text { Racial/ethnic } \\
\text { background }\end{array}$} & \multirow[t]{2}{*}{ Samples } & \multirow{2}{*}{$\begin{array}{l}\mathrm{Hb} \\
(\mathrm{g} / \mathrm{dL})\end{array}$} & \multirow{2}{*}{$\begin{array}{l}\mathrm{MCV} \\
\text { (fL) }\end{array}$} & \multicolumn{2}{|c|}{$\mathrm{Hb} \mathrm{X}(\%)$} & \multirow{2}{*}{$\begin{array}{l}\mathrm{Hb} \mathrm{E} \\
(\%)\end{array}$} & \multirow{2}{*}{$\begin{array}{l}\text { Number of } \\
\alpha \text {-globin genes }\end{array}$} & \multirow[t]{2}{*}{ References } \\
\hline & & & & & $H B \propto 1$ & $H B \propto 2$ & & & \\
\hline \multicolumn{10}{|l|}{ p.N9S (c.29A>G) } \\
\hline $\begin{array}{l}\text { Hb Zurich-Hottingen } \\
\text { p.E27D }(\text { c. } 84 G>C)\end{array}$ & Portuguese & 1 & 16.5 & 91 & - & N.M. & - & $-\alpha / \alpha \alpha$ & {$[24]$} \\
\hline Hb Hekinan & N.A. & 1 & 10.9 & 83.9 & - & 23 & & $-\alpha / \alpha \alpha$ & [14] \\
\hline Hb Hekinan & Asian & 1 & 11.3 & 69 & 15.8 & - & 80 & $-\alpha / \alpha \alpha$ & This report \\
\hline Hb Hekinan & Thai & 1 & 10.2 & 83 & 27 & - & 10 & $--/ \alpha \alpha$ & {$[39]$} \\
\hline Hb Hekinan & Thai & 1 & 8.2 & 68.6 & 26.5 & - & 9.1 & $--/ \alpha \alpha$ & [39] \\
\hline $\begin{array}{l}\text { Hb Hekinan } \\
\text { p.H50Q (c.153C >G) }\end{array}$ & Burmanese & 1 & 11.2 & 68 & 25 & - & - & $--/ \alpha \alpha$ & {$[40]$} \\
\hline $\begin{array}{l}\text { Hb Frankfurt } \\
\text { p.V55A }(\text { c. } 167 \mathrm{~T}>\mathrm{C})\end{array}$ & Portuguese & 1 & 15.2 & 83 & - & 36 & & $-\alpha / \alpha \alpha$ & {$[5]$} \\
\hline $\mathrm{Hb}$ Gerland & French & 1 & 12.2 & 70.6 & 31 & - & - & $-\alpha / \alpha \alpha$ & [29] \\
\hline $\begin{array}{l}\text { Hb Gerland } \\
\text { p.D75Y (c.226G >T) }\end{array}$ & French & 1 & 13 & 76 & 31 & - & - & $-\alpha / \alpha \alpha$ & [29] \\
\hline $\begin{array}{l}\text { Hb Winnipeg } \\
\text { p.N78K (c.237C >G) }\end{array}$ & Greek & 1 & 14.2 & 76.7 & - & 30.1 & - & $-\alpha / \alpha \alpha$ & This report \\
\hline Hb Stanleyville-II & Black & 1 & 11.7 & 87 & 28.6 & - & & $-\alpha / \alpha \alpha$ & This report \\
\hline Hb Stanleyville-II & Black & 1 & 9.3 & 89 & 25.2 & - & - & $-\alpha / \alpha \alpha$ & This report \\
\hline $\mathrm{Hb}$ Stanleyville-II & Caucasian & 1 & 15.1 & 80 & - & 27.4 & & $-\alpha / \alpha \alpha$ & This report \\
\hline
\end{tabular}

The number of $\alpha$-globin genes is also provided

N.A. not available, N.M. not measurable

paralogue genes, were identified during this study. From these, nine $\alpha$-globin chain variants were identified in our study sample, and their hematological and DNA findings were comparatively analyzed with the same $\mathrm{Hb}$ variant carriers previously published and documented in HbVar, namely $\mathrm{Hb}$ Winnipeg (51 and ten cases, respectively), $\mathrm{Hb} \mathrm{J}-$ Meerut (15 and two cases, respectively), Hb Hasharon (12 and three cases, respectively), $\mathrm{Hb}$ Lamentin (eight and one cases, respectively), $\mathrm{Hb}$ J-Paris (five and three cases, respectively), $\mathrm{Hb}$ Stanleyville-II (five and 11 cases, respectively), $\mathrm{Hb}$ Russ (two and two cases, respectively), $\mathrm{Hb}$ Toulon (two and three cases, respectively), and Hb Hekinan (one and nine cases, respectively). Also, five more $\mathrm{Hb}$ variants, resulting from identical mutations on either one of the two human $\alpha$-globin paralogue genes, were selected from $\mathrm{HbVar}$ database and/or the literature and included in this study, namely $\mathrm{Hb}$ Zurich-Hottingen/Hb Anadour (four cases), $\mathrm{Hb}$ Frankfurt (three cases), Hb Gerland (four cases), $\mathrm{Hb} \mathrm{St}$. Truiden/Hb Jeddah (four cases), and $\mathrm{Hb}$ Titusville (five cases). The hematological indices of the subjects carrying these $\alpha$-globin chain variants are provided in Tables 2 and 3. With the exception of the mildly unstable $\mathrm{Hb}$ Russ and $\mathrm{Hb}$ Gerland, the rest of the $\mathrm{Hb}$ variants were stable. Furthermore, all $\mathrm{Hb}$ variant were found in chromosomes bearing two $\alpha$-globin genes, except Hb Frankfurt, where the variant was also found in the context of a $-\alpha^{3.7}$ thalassemia chromosome [5]. All heterozygous or com- pound heterozygous (with $-\alpha^{3.7}$ thalassemia) cases were asymptomatic or present with a typical $\alpha$-thalassemia carrier phenotype, respectively.

Interestingly, however, DNA analysis of the $H B A 1$ and $H B A 2$ genes revealed that in 23 unrelated $\mathrm{Hb}$ variant carriers, the mutated $\alpha$-globin gene was different than the one previously described for each $\mathrm{Hb}$ variant. In particular, we identified $\mathrm{Hb}$ Hasharon and $\mathrm{Hb}$ Toulon resulting from an $H B A 1$, instead of a $H B A 2$, gene mutation; $\mathrm{Hb}$ Russ and $\mathrm{Hb}$ Winnipeg resulting from a $H B A 2$, instead of a $H B A 1$, gene mutation; while $\mathrm{Hb}$ Stanleyville-II mutation was found in both the HBA1 or HBA2 genes (Tables 2 and 3). The mutated gene for Hb Stanleyville-II was previously not known, as this variant was only characterized at the protein level [12].

Subsequently, we exploited the large number of unrelated $\mathrm{Hb}$ Winnipeg carriers bearing the c.226G $>\mathrm{T}$ mutation in either the $H B A 2$ or $H B A 1$ gene to address whether the percentage of the $\mathrm{Hb}$ variant can be correlated to the $\alpha$ globin gene mutation. Statistical analysis, using SPSS 10 software, showed that $\mathrm{Hb}$ Winnipeg carriers cluster in two distinct groups, determined by the percentage of the $\mathrm{Hb}$ Winnipeg variant. In $38 \mathrm{Hb}$ Winnipeg carriers bearing the HBA1 gene mutation, $\mathrm{Hb}$ Winnipeg percentage varied from 10.3 to $14.2(13.0 \pm 0.7)$, while in $12 \mathrm{Hb}$ Winnipeg carriers bearing the $H B A 2$ gene mutation, the percentage of the variant hemoglobin was between 15.6 and $18.4(16.9 \pm 0.9$, 
Fig. 1). The ration of the average percentage of the abnormal $\mathrm{Hb}$ in heterozygotes with $H B A 2(\alpha 2)$ and $H B A 1$ mutations $(\alpha 1)$ varied from 1.1 to 1.8 , with a mean value of 1.3. These results showed that (1) Hb Winnipeg is produced at a higher rate (approx. 23\%) when the underlying mutation is in the $H B A 2$ gene, and (2) the percentage of $\mathrm{Hb}$ variant could provide initial information regarding the $\alpha$-globin gene molecular defect.

We then explored the HbVar database to identify other $\mathrm{Hb}$ variants with similar properties, e.g., identical mutations in different $\alpha$-globin genes yielding the same $\alpha$-globin chain variant. We identified 64 heterozygous and compound heterozygous, with $-\alpha^{3.7}$ thalassemia cases, originating from various ethnic backgrounds (Tables 2 and 3), creating a total of 14 different $\mathrm{Hb}$ variants that fall into this category. Comparative analysis of all 165 carriers, stratified on the basis of the $\mathrm{Hb}$ variant, showed that the $\alpha 2 / \alpha 1$ average $\mathrm{Hb}$ variant percentage ranged from 0.98 to 1.67 . However, these cases were extremely rare, and therefore, their comparative analysis does not provide statistical confidence compared to the $\mathrm{Hb}$ Winnipeg cases. Finally, in three cases, the variant $\mathrm{Hb}$ was only characterized by means of protein sequencing; therefore, the mutated $\alpha$ globin gene could not be identified unambiguously, and these cases were excluded from further analysis.

\section{Discussion}

The present study reports the identification and a comparative analysis of the hematological and molecular properties of $\mathrm{Hb}$ variants resulting from the same mutation but residing on a different $\alpha$-globin gene. Our effort was facilitated from the extensive and diverse sample and comprehensive data

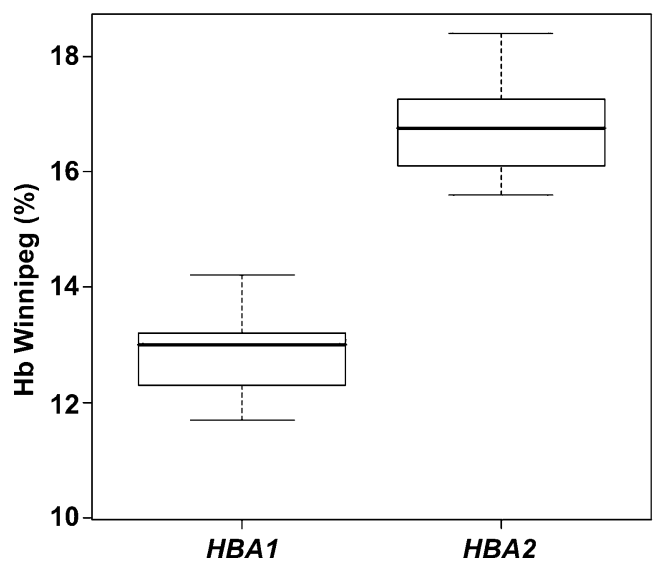

Fig. 1 Box plots $(p<0.001)$ indicating the range and mean values (thick black lines) of the $\mathrm{Hb}$ Winnipeg variant percentage between carriers bearing the $H B A 1$ or $H B A 2$ mutation. In our evaluation, the $\mathrm{Hb}$ Winnipeg/ $\alpha$-thalassemia compound heterozygous case, as well as the cases described in Ref. [32], is excluded recording of large diagnostic centers and reference laboratories participating in this study, most of which are members of the ITHANET network (http://www.ithanet.eu).

Structural variants have provided important insights into $\alpha$ globin gene transcriptional regulation and translation. In particular, using in vitro translation experiments, it has been shown that the $H B A 2$ gene encodes two- to threefold more protein that the $H B A 1$ gene [13]. However, a more detailed study of heterozygous cases for an $\alpha$-globin gene structural variant showed that the average abnormal $\mathrm{Hb}$ percentage in heterozygotes with $H B A 2$ and $H B A 1$ mutations correspond to a $\alpha 2 / \alpha 1$ ratio of $1.19 / 1$, respectively [14]. This ratio, however, was obtained from the cumulative analysis of all $\alpha$ globin chain variants, and the relative position of the variant amino acid in the $\alpha$-globin chain or the relative stability of the variant $\mathrm{Hb}$ was not taken into account. The latter may impact on the final amount of $\alpha$-globin chain, particularly for unstable variants, the translational efficiency or the altered efficiency in hemoglobin tetramer formation. Although the $\mathrm{Hb}$ variant carriers reported herein are phenotypically silent, this study provides a much safer approach, since the comparison is more direct and performed between identical mutations in the $\alpha$-globin genes, yielding identical globin chains. To our knowledge, this is the first attempt to comparatively analyze the mutations in gene paralogues leading to an identical protein product based on data collected from such a large multiethnic sample, not only for the $\alpha$-globin but also for other gene families.

Our data show that the $\alpha 2 / \alpha 1$ ratio of the average percentage of the abnormal $\mathrm{Hb}$ in heterozygotes with $H B A 2$ and $H B A 1$ mutations, respectively, varies from 0.98 ( $\mathrm{Hb} \mathrm{J}-$ Paris-I) to 1.67 (Hb Gerland; Tables 2 and 3). Moreover, comparison of the $\alpha 2 / \alpha 1$ ratio of the average percentage of the abnormal Hbs showed that stable and mildly unstable abnormal Hbs nicely cluster in two distinct groups with average $\alpha 2 / \alpha 1$ ratios of $1.15 \pm 0.10$ and $1.60 \pm 0.09$, respectively (Fig. 2). Notably, in all cases summarized in Tables 2 and 3 , the percentage of variant $\mathrm{Hb}$ has been calculated using cation-exchange HPLC. Therefore, although these values come from different centers and published reports, the use of similar analytical method, apparatus, and analysis software makes these values virtually comparable. Also, the large number of $\mathrm{Hb}$ Winnipeg cases studied in this context statistically strengthens the above claims (Table 2). These data are comparable with previous results from heterozygous cases for 24 different $\alpha$-globin chain variants [14] but sharply contradicts with a previous study [13], which indicated that a mutated $H B A 2$ gene yielding a variant $\alpha$ globin chain is expressed at a two- to threefold higher level than a mutated $H B A 1$ gene. The main supporting data for this claim were the $\mathrm{Hb}$ levels of $\mathrm{Hb} \mathrm{J}-\mathrm{Oxford}(40 \%)$ and $\mathrm{Hb}$ Hasharon (35\%), which are comparable to levels expected for $\mathrm{Hb}$ variant $/ \alpha$-thalassemia compound heterozygotes (see 
Fig. 2 Comparison of the calculated $\alpha 2 / \alpha 1$ ratio of the average percentage of the stable $(S$, shown in blue bars) and mildly unstable abnormal $\mathrm{Hbs}(M U$, shown in red bars) reported in this paper

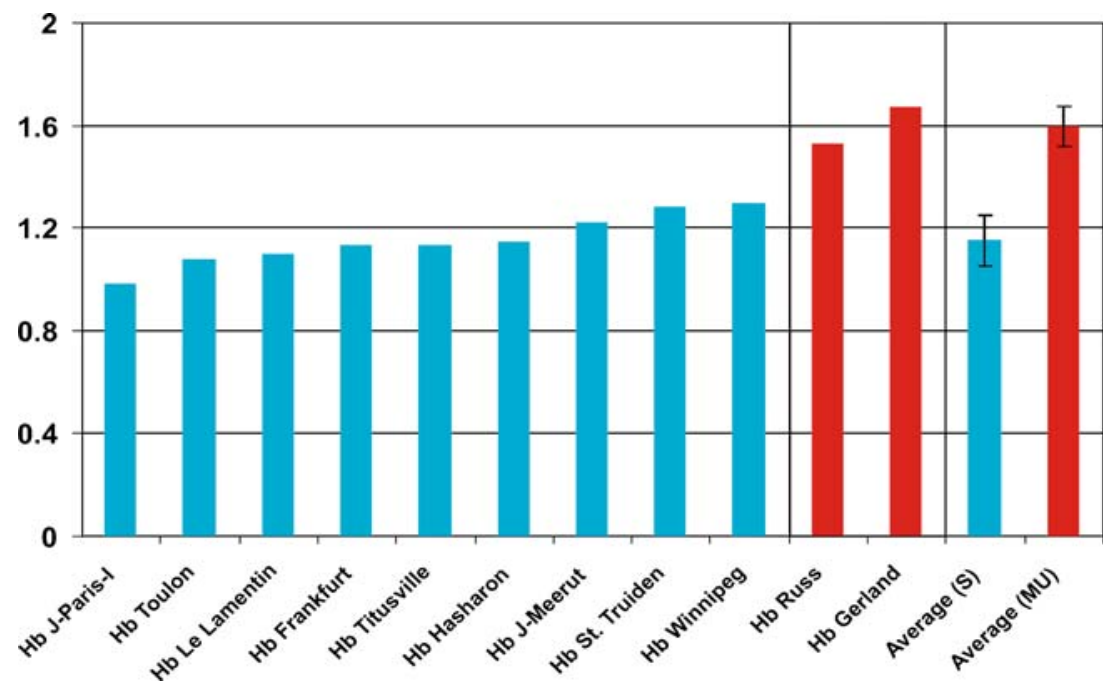

also Table 3). However, these data were obtained from in vitro translation experiments, and hence, this discrepancy is most likely due to the experimental approach rather that directly measuring $\mathrm{Hb}$ variant levels in vivo.

How do these variants occur? Although recurrent mutational events can be a likely cause for some of them, interallelic gene conversion event is the most plausible cause that might have resulted in the same mutation being "transferred" into different genomic contexts. A handful of examples also exist in the human $\beta$-like globin genes (reviewed in [15]), as well as in other human multigene families [16]. In favor for this assumption is the fact that 13 out of $14 \mathrm{Hb}$ variants described herein are within exons 1 and 2 . These exons, and not exon 3 , have been shown to be involved in gene conversion events, as the $3^{\prime}$ end of the human $\alpha$-globin gene conversion tract is located in intron II (Fig. 3).

Importantly, however, the ethnic background of the family or the individual where the mutation is found cannot be always indicative for the likely mechanism that resulted in the mutation in question. For example, the plethora of $\mathrm{Hb}$ Winnipeg observed in the French population may indicate recurrent gene conversion events. However, in the cases of $\mathrm{Hb}$
Gerland and $\mathrm{Hb}$ Stanleyville-II, although the variants have been reported in two families from France and Southeast Asia and in Caucasian and Black families, respectively, recurrent mutations and (recurrent) gene conversion events are equally likely mechanisms to have generated the mutations in the $H B A 2$ and $H B A 1$ genes, and thorough haplotype analysis is required to favor one mechanism over the other.

Apart from gene conversion events, recurrent unequal crossovers cannot be completely ruled out as a likely cause of these $\mathrm{Hb}$ variants. Unequal crossovers have been previously shown to be frequent in the human $\alpha$-globin gene family $[17,18]$. In particular, two successive unequal crossover events, i.e., from a normal $(\alpha \alpha)$ to a rearranged [e.g., deletional $(\alpha-)$ or triplicated $(\alpha \alpha \alpha)$ ] chromosome and back, will be undistinguishable from a gene conversion event and have the same consequence, e.g., transfer of a DNA segment from one $\alpha$-globin gene to another. The rearranged (intermediate) chromosome bearing the variant nucleotide can either persist in the population and, therefore, be found, as in the case of Hb Frankfurt [5] or can subsequently be lost.

In general, gene conversion events can be identified from neighboring to the mutation paralogous sequence

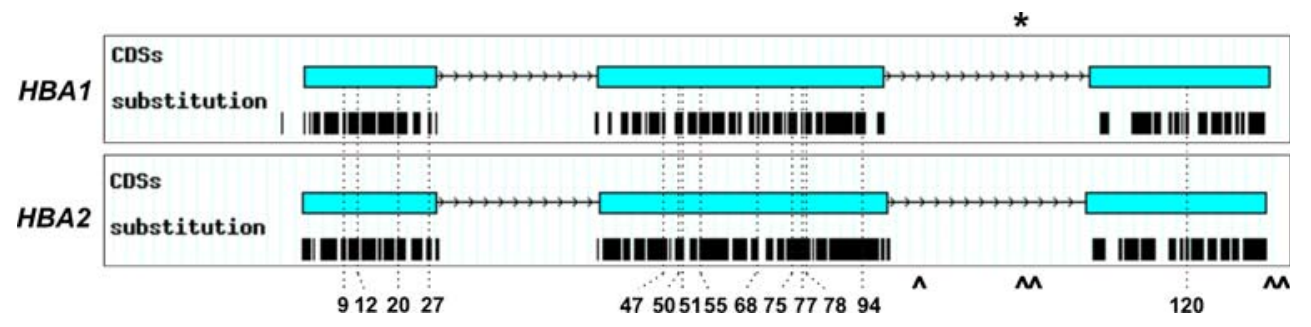

Fig. 3 Schematic drawing of the $14 \alpha$-globin chain variants resulting from an identical mutation in either the $H B A 1$ or $H B A 2$ genes. Original graphs have been automatically generated by HbVar graphical display [8]. Thick lines under each coding sequence (CDS) represent the position of each substitution deposited in HbVar. Asterisk $3^{\prime}$ end of the human $\alpha$-globin gene conversion tract [6], caret PSVs in the promoter and coding sequences of the human $\alpha$-globin genes

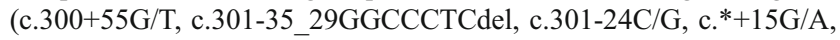
c. $\left.{ }^{*}+19 \mathrm{~A} / \mathrm{G}\right)$ deducted from sequence comparison between the $H B A 2$ and HBA1 reference sequences (NG_000006.1; see also Supplementary data) 
variants (PSVs) that are also transferred along with the mutation. Therefore, PSVs are valuable, as they provide insights regarding the length of the gene conversion tract. The Cretan type of non-deletional hereditary persistence of fetal hemoglobin stands as a representative example [19, 20]. $H B A 2$ and $H B A 1$ genes have several PSVs outside the 1,436-bp $\alpha$-globin gene converted region, spanning from positions -868 to +568 relative to the genes' transcriptional initiation site [4], but very few PSVs within this DNA segment (depicted as "^" in Fig. 3; see also Supplementary data). Therefore, it is very difficult to unambiguously distinguish these recombinational events from recurrent mutations. At present, there is only one well-documented mutagenic gene conversion event in the human $\alpha$-globin gene locus ( $\mathrm{Hb} \mathrm{I}$; p.K16E) identified in both $H B A 1$ and $H B A 2$ genes in cis [6]. This resembles $\mathrm{Hb}$ F-Charlotte [HBG1:p.I75T and p.A136E; 21], contrary to Hb F-Waynesboro and $\mathrm{Hb}$ F-Lesvos [22], which resulted from the same mutation but in the $H B G 2$ gene (HBG2:p.I75T). Also, two variant $\alpha$-globin gene alleles consisting of a small DNA segment from the other $\alpha$-globin gene paralogue $(\alpha 212$ and $\alpha 121)$ are most likely the result of a single crossover between a normal and a recombinant allele, although a non-reciprocal gene conversion event cannot be completely ruled out [23]. In all cases, extended haplotype analysis around these variants is an absolute requirement, although this is beyond the scope of the present study.

From a formal genetic point of view, despite the fact that these mutations lead to an identical globin chain, they must be considered as different mutational events, since the nucleotide change occurs in another gene. These situations often cause ambiguities when depositing relevant data in locus-specific databases, like HbVar [1]. The same situation is also reported for two mutations leading to $\alpha$-thalassemia, namely the c. $95+5 \mathrm{G}>\mathrm{A}$ mutation, found on both $\alpha$-globin genes and the c. $1 \mathrm{~A}>\mathrm{G}$ (initiation codon mutation), found on both $H B A 2$ and $H B A 1$ genes and in a hybrid $\alpha$-globin gene in the context of $\alpha^{-3.7}$ thalassemia chromosome. In addition, apart from the $\mathrm{Hb}$ variants reported herein, there are also $\mathrm{Hb}$ variants for which the amino acid change is identical, but the nucleotide change is different. Such $\mathrm{Hb}$ variants are clearly the products of independent mutational events, namely Hb G-Philadelphia (p.N68K; HBA2:c.207C $>$ A or HBA1:c. 207C $>\mathrm{G}$ ), Hb J-Broussais (p.K90N; HBA2: c. $273 \mathrm{G}>\mathrm{T}$ or $H B A 1: \mathrm{c} .273 \mathrm{G}>\mathrm{C}$ ), and $\mathrm{Hb}$ Manitoba (p. S102R; HBA2:c.307A $>\mathrm{C}$ or HBA2:c.309C $>\mathrm{A}$ or HBA1: c. 309C $>\mathrm{A}$; also documented as Hb Manitoba I, III, and II, respectively). Therefore, we propose the use of an appropriate suffix in the corresponding variant's name as a solution to this issue. We propose the use of the [A1] suffix for $\mathrm{Hb}$ variants due to $H B A 1$ gene and [A2] suffix for $\mathrm{HBA} 2$ gene mutations, e.g., $\mathrm{Hb}$ Winnipeg [A1] and $\mathrm{Hb}$ Winnipeg [A2], referring to the HBA1:c.226G $>\mathrm{C}$ and
HBA2:c.226G $>\mathrm{C}$ mutations, respectively. This proposed nomenclature is different than the one used for $\delta$-globin chain variants, e.g., $\mathrm{Hb} \mathrm{A}_{2}$-Yialousa, to avoid confusion.

Acknowledgments This work has been the outcome of a collaborative project among FP6 eInfrastructure for Thalassaemia Research Network (ITHANET, RI-2004-026539; http://www.ithanet.eu) and external partners, proposed and coordinated by Erasmus MC, and supported by ITHANET. We are indebted to Dr. Giovanni Ivaldi, Mrs. Sofia Parastratidou, Mr. Jean Riou, Mrs. Eleni Ranou, Miss Emily Lamb, Mrs. Janice McMcarthy, and Mrs. Athina Ritsiou for expert technical assistance.

Open Access This article is distributed under the terms of the Creative Commons Attribution Noncommercial License which permits any noncommercial use, distribution, and reproduction in any medium, provided the original author(s) and source are credited.

\section{References}

1. Hardison RC, Chui DHK, Giardine B, Reimer C, Patrinos GP, Anagnou $\mathrm{N}$ et al (2002) Hb Var: A relational database of human hemoglobin variants and thalassemia mutations at the globin gene server. Hum Mutat 19:225-233 doi:10.1002/humu.10044

2. Patrinos GP, Wajcman H (2004) Recording human globin gene variation. Hemoglobin 28:v-vii

3. Patrinos GP, Giardine B, Riemer C, Miller W, Chui DH, Anagnou $\mathrm{NP}$ et al (2004) Improvements in the HbVar human hemoglobin variants and thalassemia mutations for population and sequence variation studies. Nucleic Acids Res 32:D537-D541 doi:10.1093/ nar/gkh006

4. Michelson AM, Orkin SH (1983) Boundaries of gene conversion within the duplicated human alpha-globin genes. Concerted evolution by segmental recombination. J Biol Chem 258:15245-15254

5. Préhu C, Francina A, Behnken LJ, Prome D, Galacteros F, Wajcman $\mathrm{H}$ (2003) An identical mutation carried by different genes: $\mathrm{Hb}$ Frankfurt. Haematologica 88:ECR19 alpha50(CE8)His->Gln

6. Liebhaber SA, Rappaport EF, Cash FE, Ballas SK, Schwartz E, Surrey S (1984) Hemoglobin I mutation encoded at both alphaglobin loci on the same chromosome: concerted evolution in the human genome. Science 226:1449-1451 doi:10.1126/science. 6505702

7. Giardine B, Riemer C, Hefferon T, Thomas D, Hsu F, Zielenski J et al (2007) PhenCode: connecting ENCODE data with mutations and phenotype. Hum Mutat 28:554-562 doi:10.1002/humu.20484

8. Giardine B, van Baal S, Kaimakis P, Riemer C, Miller W, Samara $M$ et al (2007) HbVar database of human hemoglobin variants and thalassemia mutations: 2007 update. Hum Mutat 28:206 doi:10.1002/humu.9479

9. Wajcman H, Préhu C, Bardakdjian-Michau J, Promé D, Riou J, Godart C et al (2001) Abnormal hemoglobins: the laboratory methods. Hemoglobin 25:169-181 doi:10.1081/HEM-100104026

10. Lorey F, Charoenkwan P, Witkowska HE, Lafferty J, Patterson M, Eng B et al (2001) Hb H hydrops foetalis syndrome: a case report and review of literature. Br J Haematol 115:72-78 doi:10.1046/ j.1365-2141.2001.03080.x

11. Tan AC, Quah TC, Low PS, Chong SS (2001) A rapid and reliable 7-deletion multiplex polymerase chain reaction assay for alpha-thalassemia. Blood 98:250-251 doi:10.1182/blood. V98.1.250

12. Van Ros G, Beale D, Lehmann H (1968) Haemoglobin Stanleyville II (alpha asparagine replaced by lysine). BMJ 4:92-93 
13. Liebhaber SA, Cash FE, Ballas SK (1986) Human alpha-globin gene expression. The dominant role of the alpha 2-locus in mRNA and protein synthesis. J Biol Chem 261:15327-15333

14. Molchanova TP, Pobedimskaya DD, Huisman TH (1994) The differences in quantities of alpha 2- and alpha 1-globin gene variants in heterozygotes. Br J Haematol 88:300-306 doi:10.1111/ j.1365-2141.1994.tb05022.x

15. Papadakis MN, Patrinos GP (1999) Contribution of gene conversion in the evolution of the human beta-like globin gene family. Hum Genet 104:117-125 doi:10.1007/s004390050923

16. Chen JM, Cooper DN, Chuzhanova N, Férec C, Patrinos GP (2007) Gene conversion: mechanisms, evolution and human disease. Nat Rev Genet 8:762-775 doi:10.1038/nrg2193

17. Lam KW, Jeffreys AJ (2006) Processes of copy-number change in human DNA: the dynamics of \{alpha\}-globin gene deletion. Proc Natl Acad Sci U S A 103:8921-8927 doi:10.1073/pnas.0602690103

18. Lam KW, Jeffreys AJ (2007) Processes of de novo duplication of human alpha-globin genes. Proc Natl Acad Sci U S A 104:1095010955 doi:10.1073/pnas.0703856104

19. Patrinos GP, Kollia P, Loutradi-Anagnostou A, Loukopoulos D, Papadakis MN (1998) The Cretan type of non-deletional hereditary persistence of fetal hemoglobin [A gamma-158C $>\mathrm{T}$ ] results from two independent gene conversion events. Hum Genet 102:629-634 doi:10.1007/s004390050753

20. Kalamaras A, Chassanidis C, Samara MBB, Chiotoglou I, Vamvakopoulos NK, Papadakis MN et al (2008) The 5' regulatory region of the human fetal globin genes is a gene conversion hot spot. Hemoglobin (in press)

21. Gu LH, Oner C, Huisman TH (1995) The G gamma T chain $(G$ gamma $75 \mathrm{Thr}$; $136 \mathrm{Gly}$ ) in $\mathrm{Hb}$ F-Charlotte is the product of an A gamma gene with a limited gene conversion and that in $\mathrm{Hb} \mathrm{F}$ Waynesboro of a mutated G gamma gene. Hemoglobin 19:413418 doi:10.3109/03630269509005834

22. Papadakis MN, Patrinos GP, Drakoulakou O, Loutradi-Anagnostou A (1996) HbF-Lesvos: an $\mathrm{HbF}$ variant due to a novel $\mathrm{G}$ gamma mutation (:G gamma 75 ATA->ACA) detected in a Greek family. Hum Genet 97:260-262 doi:10.1007/BF02265278

23. Law HY, Luo HY, Wang W, Ho JF, Najmabadi H, Ng IS et al (2006) Determining the cause of patchwork HBA1 and HBA2 genes: recurrent gene conversion or crossing over fixation events. Haematologica 91:297-302

24. Troxler H, Neuheiser F, Kleinert P, Kuster T, Heizmann CW, Sack $R$ et al (2002) Detection of a novel variant human hemoglobin by electrospray ionization mass spectrometry. Biochem Biophys Res Commun 292:1044-1047 doi:10.1006/bbrc.2002.6762

25. Zhao W, Wilson JB, Webber BB, Kutlar A, Tamagnini GP, Kuam $B$ et al (1990) Hb Hekinan observed in three Chinese from Macau; identification of the GAG-GAT mutation in the alpha 1-globin gene. Hemoglobin 14:627-635 doi:10.3109/03630269009046971

26. Shih HC, Shih MC, Chang YC, Peng CT, Chang TJ, Chang JG (2007) Hb Hekinan in a Taiwanese subject: A G>T substitution at codon 27 of the alpha1-globin gene abolishes an HaeIII site. Hemoglobin 31:495-498 doi:10.1080/03630260701590368

27. Merault G, Keclard L, Desfontaines L, Saint-Martin C, Blouquit Y, Rosa J et al (1989) Hemoglobin Hekinan [alpha (2)27(B8)Glu-
Asp beta 2] detected in Guyana. Hemoglobin 13:397-402 doi:10.3109/03630268909003402

28. Liebhaber SA, Kan YW (1981) Differentiation of the mRNA transcripts originating from the alpha 1- and alpha 2-globin loci in normals and alpha-thalassemics. J Clin Invest 68:439-446 doi:10.1172/JCI110273

29. Lacan P, Aubry M, Couprie N, Francina A (2001) Hb Gerland [alpha55(E4)Val->Ala (alpha2)]: a new neutral alpha chain variant involving the alpha2 gene. Hemoglobin 25:417-420 doi:10.1081/ HEM-100107879

30. Moradkhani K, Riou J, Francina A, Wajcman H, Prehu C (2008) $\mathrm{Hb}$ Gerland [55(E4)Val $>\mathrm{Ala}]$ mutation found in the alphal gene. Hemoglobin (in press)

31. Markley KM, Elkhalifa M, Maini A, Hoyer JD (2008) Hemoglobin Jeddah $[\alpha 68$ (E17) Asn $>$ His (alpha1)]: a newly recognized alpha chain variant seen in combination with hemoglobin $\mathrm{S}$ and found in three separate families of Middle Eastern origin. Hemoglobin 32:297-302 doi:10.1080/03630260701758908

32. Nakatsuji T, Abraham BL, Lam H, Wilson JB, Huisman TH (1983) Hb Winnipeg or alpha 2 75(EF4)Asp leads to Tyr beta 2 in a large Caucasian family living in Georgia, USA. Hemoglobin 7:105-110 doi:10.3109/03630268309038407

33. Badens C, Léna-Russo D, Lacan P, Francina A, Promé D, Riou J et al (1999) Hb Toulon [alpha77(EF6)Pro>His]: a new variant due to a mutation in the alpha2 gene found during measurement of glycated hemoglobin. Hemoglobin 23:367-371

34. Waye JS, Eng B, Chui DHK, Powers PJ, Lafferty JD (2000) Second report of $\mathrm{Hb}$ Toulon [alpha77(EF6)Pro $>\mathrm{His}$ ] in a Canadian family of Italian descent. Hemoglobin 24:359-360

35. Caruso D, Da Riva L, Giavarini F, Galli G, Brambilla S, Luraschi $P$ et al (2002) A hemoglobin variant found during glycohemoglobin measurement, identified as Hb Toulon [alpha77(EF6)Pro$>$ His] by tandem mass spectrometry. Hemoglobin 26:197-199 doi:10.1081/HEM-120005460

36. North ML, Darbre PD, Lehmann H, Juif JG (1975) Haemoglobin Stanleyville II (alpha75 [EF 7] Asn yields Lys) found in France. Acta Haematol 53:56-59

37. Luo HY, Irving I, Prior J, Lim E, Eung SH, Skelton TP et al (2004) Hemoglobin Titusville, a low oxygen affinity variant hemoglobin, in a family of Northern European background. Am J Hematol 77:384-386 doi:10.1002/ajh.20209

38. Deyell R, Jackson S, Spier S, Le D, Poon MC (2006) Low oxygen saturation by pulse oximetry may be associated with a low oxygen affinity hemoglobin variant, hemoglobin Titusville. J Pediatr Hematol Oncol 28:100-102 doi:10.1097/01.mph.0000200685. 33291.0a

39. Fucharoen S, Changtrakun Y, Ratanasiri T, Fucharoen G, Sanchaisuriya K (2003) Complex interaction of Hb Hekinan [alpha27(B8) Glu-Asp] and Hb E [beta26(B8) Glu-Lys] with a deletional alpha-thalassemia 1 in a Thai family. Eur J Haematol 70:304-309 doi:10.1034/j.1600-0609.2003.00049.x

40. Ngiwsara L, Srisomsap C, Winichagoon P, Fucharoen S, Svasti J (2004) Two cases of compound heterozygosity for Hb Hekinan [alpha27(B8)Glu->Asp (alpha1)] and alpha-thalassemia in Thailand. Hemoglobin 28:145-150 doi:10.1081/HEM-120035913 